\title{
Daily and seasonal estimates of the recruitment and biomass of glass eels runs (Anguilla anguilla) and exploitation rates in the Adour open estuary (Southwestern France)
}

\author{
Noëlle Bru ${ }^{1, a}$, Patrick Prouzet ${ }^{2, a}$ and Michel Lejeune ${ }^{3}$ \\ ${ }^{1}$ Laboratoire de Mathématiques et ses Applications, UMR CNRS 5142, Université de Pau et des Pays de l'Adour, \\ 64013 Pau Cedex, France \\ 2 Laboratoire Ressources Halieutiques d'Aquitaine IFREMER, Campus de Montaury, Anglet, France \\ 3 Laboratoire de Statistique et Analyse des Données, BSHM, 1251 avenue centrale BP 47, 38040 Grenoble Cedex 09, France
}

Received 5 January 2009; Accepted 30 October 2009

\begin{abstract}
The European eel (Anguilla anguilla) is drastically declining in all its distribution area and listed in the red list of the IUCN (International Union for Conservation of Nature). A rebuilding plan was adopted at European level in 2007, Regulation R(CE) 100/2007, to restore eel abundance to the level observed during the seventies. Its implementation started on the $1^{\text {st }}$ of January 2009. This species is heavily threatened by numerous activities including fishing, and its management can only be effective through a systemic approach minimizing the whole range of humaninduced impacts on the resource and its habitat. In the framework of the European interregional programme INTERREG IIIB-Atlantic Area- the INDICANG project aimed at elaborating abundance indicators of the European eel in the central part of its distribution area (http://www.ifremer/fr/indicang/). A methodological guide was elaborated by this project to define the indicators needed for this resource assessment. In this framework, Ifremer (Institut Français pour l'Exploitation de la Mer) and the UPPA University (Université de Pau et des Pays de l'Adour) have developed a method to estimate the daily and seasonal biomass of glass eels with the view to evaluate the fishery's impact on the estuarine eel recruitment to the Adour catchment. The estimation method uses observations from nightly scientific surveys to estimate glass eels' densities in the water column during various flood tides characterized by different hydrodynamic conditions. Information on these conditions allows the estimation of the glass eels biomass migrating during the night. From these estimates and reported catches made by the fishery during the same night, the exploitation rate applied by the fishery on the flow of glass eels progressing upstream during night flood tides is estimated. The relationship between the exploitation rate, fishery catches and hydrodynamic conditions allowed the estimation of the exploitation rate and nocturnal biomass fluctuations during the fishing season, from November $1^{\text {st }}$ to March $31^{\text {st }}$ of the following year. Finally, from the chronological series of biomass migrating at night, the total biomass migrating every day and the total recruitment into the estuary, during the main glass eel migration period, are estimated. Estimations made between 1998 and 2005 indicate that the overall rate of exploitation of the marine and continental fisheries, on average, is of $15.7 \%$, ranging between 8 and $25 \%$ according to fishing seasons.
\end{abstract}

Key words: Biomass estimates / Exploitation rate / Time series / River / Glass eel / Anguilla anguilla

Résumé - L'anguille européenne (Anguilla anguilla) est en forte diminution dans l'ensemble de son aire de répartition et inscrite sur la liste rouge de l'IUCN (International Union for Conservation of Nature). Un plan de restauration a été décidé à l'échelle européenne en 2007 (règlement R(CE) 1100/2007) afin de permettre un retour de l'espèce à des niveaux d'abondance observés dans les années soixante-dix. Sa mise en application est effective au $1^{\text {er }}$ janvier 2009. Cette espèce est fortement impactée par de nombreux usages dont la pêche et sa gestion ne peut être correctement effectuée que par une approche systémique minimisant l'ensemble des effets des impacts anthropiques sur cette ressource et ses habitats. Dans le cadre du programme inter-régional européen INTERREG IIIB-Espace Atlantique le projet INDICANG vise à l'élaboration d'indicateurs d'abondance et de colonisation de sur l'anguille européenne dans la partie centrale de son aire de répartition (http://www.ifremer/fr/indicang/). Un guide méthodologique a été élaboré

\footnotetext{
${ }^{a}$ Corresponding author:

Noelle.bru@univ-pau.fr; Patrick.Prouzet@ifremer.fr
} 
par ce projet pour définir les indicateurs nécessaires à l'évaluation de cette ressource. Dans ce cadre, l'Institut Français pour l'Exploitation de la Mer (Ifremer) et l'Université de Pau et des Pays de l'Adour (UPPA) ont mis au point une technique d'estimation des biomasses journalières et saisonnières de civelles afin d'estimer l'impact de la pêche sur le recrutement estuarien de l'anguille dans le bassin versant de l'Adour. La méthode d'estimation utilise des observations effectuées durant des campagnes scientifiques, de nuit, afin d'estimer des densités de civelle au sein de la colonne d'eau durant différentes marées montantes caractérisées par des conditions hydrodynamiques différentes. Les informations collectées sur ces conditions permettent de déduire les biomasses de civelles migrant de nuit. A partir de ces abondances et des captures déclarées de la pêcherie pendant la même nuit, le taux d'exploitation exercé sur les flux de civelles progressant en amont durant le flot nocturne est estimé. La relation entre le taux d'exploitation, les captures professionnelles et les conditions hydrodynamiques permet d'évaluer la variation des taux d'exploitation et des biomasses migrant chaque nuit lors d'une saison de pêche allant du $1^{\mathrm{er}}$ novembre au 31 mars de l'année suivante. Enfin, la série chronologique des biomasses nocturnes permet de déduire la biomasse migrante journalière et le recrutement total pénétrant dans l'estuaire durant la principale saison de migration des civelles. Les estimations effectuées entre 1998 et 2005 indiquent que le taux d'exploitation global de la pêche professionnelle maritime et fluviale dans l'estuaire est en moyenne de $15,7 \%$ et compris entre 8 et $25 \%$ selon les saisons de pêche.

\section{Introduction}

The scientific advice from the International Council for the Exploration of the Sea (ICES) is that the stock of European eel (Anguilla anguilla) is outside safe biological limits and that current fisheries are not sustainable. ICES recommends that a recovery plan be developed for the whole stock of European eel as a matter of urgency and that exploitation and other human activities affecting the fishery or the stock be reduced as much as possible. As a consequence, on 18 September 2007, the Council of the European Union adopted a regulation (EC 1100/2007) establishing measures for the recovery of the stock of European eel (Anguilla anguilla). Moreover, in November 2007, the International Union for Conservation of Nature (IUCN) listed the European eel on its Appendix II and considered the eel as an endangered species. Consequences will include a control of the eel international trade, especially outside the natural distribution area. The eel management plans have to be adapted to regional and local conditions. All EU members have to define measures implementing the protection, conservation and enhancement of aquatic environment of eel resources and regulating the exploitation of the species at all its biological stages.

During the INDICANG project ${ }^{1}$, different studies and compilation of biological and technical knowledge have been undertaken (Adam et al. 2008a), some of which on the simulation of glass eels behavior in the lower and the upper parts of estuaries (Prouzet et al. 2008; Susperregui et al. 2007) and on estimates of glass eels recruitment and rate of exploitation exerted by the professional fisheries in an open estuary.

Following a brief summary of the biological background of the study, this paper describes the sampling design, the methodology used to estimate the daily and seasonal biomass and other fishery parameters, with an application to the Adour estuary glass eel fishery during 6 fishing seasons taken between 1998 and 2005.

${ }^{1}$ INTERREG IIIB, Atlantic Area project (Setting up of a network of indicators of the abundance and colonisation patterns of the European eel (Anguilla anguilla) in the south of the central part of its area of distribution (Prouzet 2004, http://www.ifremer.fr/indicang/).

\subsection{Biological cycle}

The biological cycle of European eel (Anguilla anguilla) is complex and many aspects of it are yet to be fully understood (Fig. 1). It is an amphihaline species that lives alternatively in fresh and sea water. A brief summary of its life cycle is provided in Prouzet et al. (2009). The spawning takes place in the Sargasso Sea in winter. The larvae, called leptocephalae, are transported eastward by the oceanic currents. In the vicinity of the continental shelf, the larvae transform into glass eels that colonize an area located between Mauritania and the Baltic Sea, including the Mediterranean Sea. When glass eels arrive at the mouth of an estuary, their entry in freshwater is linked to physical conditions such as salinity, temperature, river flow and tide coefficient (Edeline et al. 2005, 2006; Adam et al. 2008; Jellyman et al. 2009).

The migratory behavior of glass eels according environmental conditions is detailed by Adam et al. (2008a) and Rigaud et al. (2008). For a better understanding of the sampling design used to estimate densities of glass eels during their upstream migration through the estuary, we will just recall the following biological information:

- On average hydrological conditions, glass eels penetrate in low or medium density in the estuary following the rhythm of flood tides (Bolliet and Labonne 2008). It is mainly a passive migration upstream (McCleave and Wippelhauser 1987), but with the position in the water column depending on environmental conditions and more particularly on lighting. In turbid water, migrating individuals are found through the entire water column, whatever the phase of the lunar cycle. In clear water, they move close to the bottom, especially during full moon (De Casamajor et al. 1999).

- The catchability of glass eels depends on hydrodynamic conditions. It is maximal when the water is turbid and the upstream migration is slow (i.e. in the case of an association of a low and medium tide coefficient with a medium outgoing river flow).

- Accumulation of groups of glass eels in the lower part of estuary is often observed during river floods period. The hydrodynamic simulations made on the Adour estuary showed retention and accumulation of glass eel runs by hydrodynamic features e.g. in case of combination of 


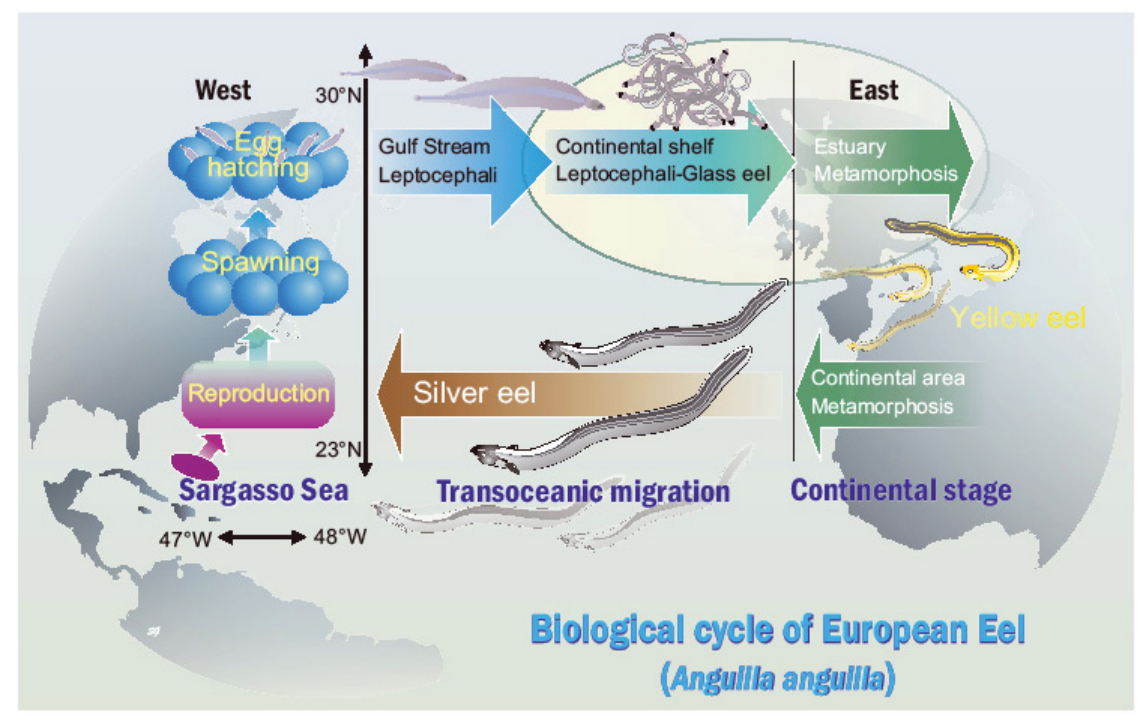

Fig. 1. Biological cycle of the European eel (Anguilla anguilla).

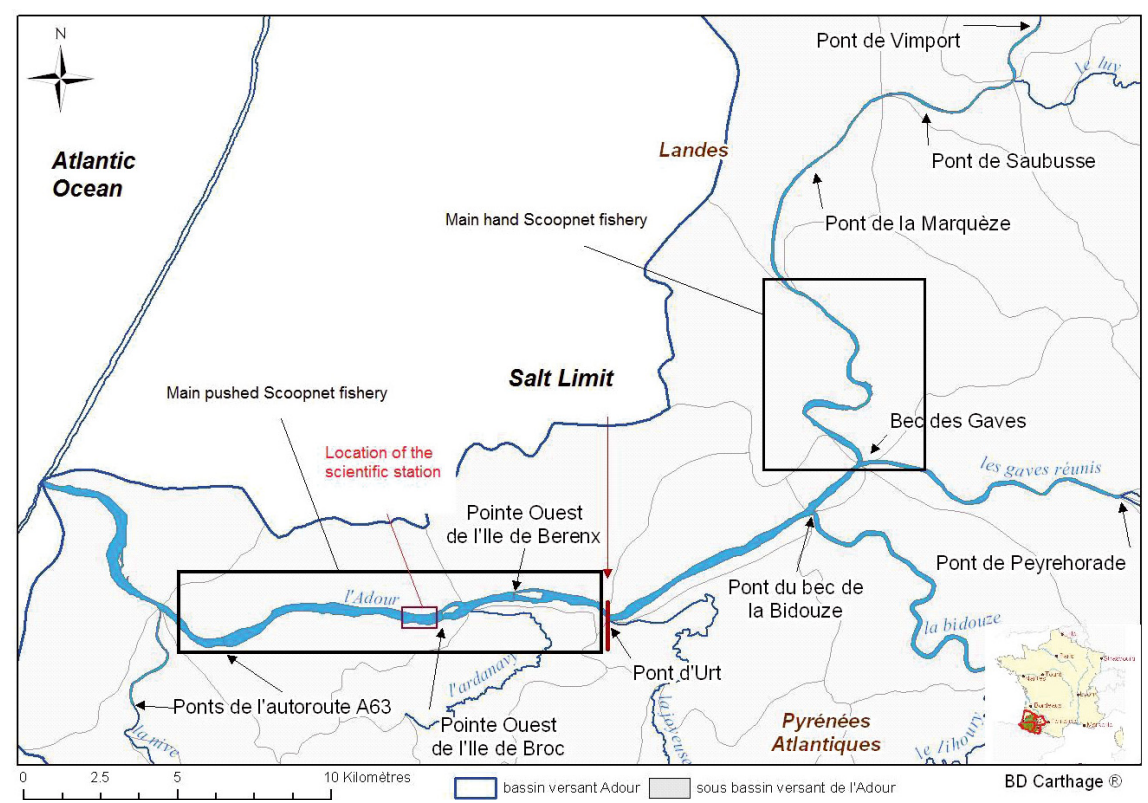

Fig. 2. The Adour estuary and locations of hand and push scoopnet fisheries and the scientific station.

low or medium tide coefficients with high river flow. In the average hydrological conditions prevailing during the migration season (October to March), the migration speed may be equal to the displacement of the tide $\left(0.4 \mathrm{~m} \mathrm{~s}^{-1}\right)$ and the time necessary to travel around $10 \mathrm{~km}$ of estuary is about one day (or two rising tides - of 4 hours each in the medium part of the estuary (Prouzet et al. 2009).

After this pelagic phase corresponding to eel recruitment, a benthic behavior and a phase of settlement are observed in different habitats: estuaries, salted marshes, lagoons, coastal waters and continental waters. The diffusion of elvers (recently settled pigmented glass eels) into the upstream part of the estuaries and the lower and medium courses of the rivers occurs according to some poorly known regulation mechanisms (Adam et al. 2008b).

\subsection{The fisheries}

The Adour river glass eels fishery is a very valuable activity for the marine fishers operating in an area located mainly between the confluence of the Adour with the Nive river and $10 \mathrm{~km}$ after the confluence with "Les Gaves réunis", main tributary of the Adour river (i.e. between A and B, Fig. 2).

As on all the French rivers, catches in the Adour have decreased significantly since the eighties and the reported catches oscillated between 2 and 12 metric tons during this period 
(Prouzet et al. 2001; Lissardy et al. 2005). The fishing season takes place between November $1^{\text {st }}$ and March $31^{\text {st }}$ of the following year, i.e. for 151 days of which 121 potential fishing days (30 days of closure during the fishing season).

The boats, generally smaller than $8 \mathrm{~m}$ (Cuende et al. 2002), use two different fishing gears: the hand and push scoopnets with a square mesh size of 1 to $1.2 \mathrm{~mm}$. The first is mainly used on the Adour river above the confluence with the "Gaves réunis" (Fig. 2, B rectangle). The second is allowed exclusively below the Urt bridge (Fig. 2, A rectangle) within the first $20 \mathrm{~km}$ from the mouth of the Adour river.

The glass eels are caught during the night when the flood tide progresses in the estuary. The boats move against the tide current with one scoopnet of $1.5 \mathrm{~m}$ of diameter set on each side of the hull. The gears filter the upper layer of the water column and catch the glass eels located close to the surface or deeper if the push scoopnet has a fixed handle the length of which ranges between 3 and $8 \mathrm{~m}^{2}$. The fishers operate their gears during 5 to $20 \mathrm{~min}$ (generally $10 \mathrm{~min}$ at a speed ranging between 2 and 3 knots) and drop the catch on a plastic grid (mesh size $5 \mathrm{~mm}$ ) on top of a holding tank. On the lower part of the estuary, the volume filtered by one boat operating 2 push scoopnets ranges between 22000 and $32000 \mathrm{~m}^{3}$ per night in average hydroclimatic conditions (in terms of tide coefficient and river flow). The glass eels catch is carried to a local collecting station and then transported to the wholesaler following the removal of dead fish or by-catch (Nielssen and Prouzet 2008).

\section{Data and methods}

\subsection{Data collection}

\subsubsection{Glass eel sampling}

The data on glass eels densities are collected to estimate the nocturnal biomass flowing through a "sampling station" - i.e. a small portion of the river within which short longitudinal hauls are made to sample the glass eels - shown as a small red rectangle within the pushed scoopnet fishing area (in the lower left quadrant, Fig. 2). The position of the station has been selected for the following reasons: $(i)$ it is a rectilinear zone with no hydrodynamic turbulences, in order to have vectors of water currents parallel to the river banks; (ii) there is no thermocline or halocline impeding the dispersal of individuals in the whole water column; (iii) the area is exploited by the professional fishery and hence ideal to calculate the exploitation rate. The sampling survey was made at night during flood tide with a passive drift of glass eels moving upstream behind the hydrodynamic front. Samples were taken successively on three longitudinal transects: one near the right bank $(\mathrm{Rb})$, the other one in the middle of the river (M) and the last one near the left bank $(\mathrm{Lb})$. Two small push scoopnets are used $(0.70 \mathrm{~m}$ in diameter, $3 \mathrm{~m}$ deep and a square mesh of $1 \mathrm{~mm}$ ) hauled from a boat moving down the river (i.e. against the stream) during five minutes per transect at a speed ranging from 1 to 2 knots.

\footnotetext{
2 The handle is generally used in large estuary such as the Loire,
} but in the Adour river, the push scoopnet is used without it.
Table 1. Example of data provided by a fisher fishing for glass eel (extracted from the central data base). TAM: hand-scoopnet; PIB: push scoopnet; 2299: code for glass eel; D16E8UV, D16E8UC: fishing areas below Urt where the push scoopnet is allowed; D16E8M0, D16E8M1, D16E8M2: fishing areas above Urt where the push scoopnet is not allowed.

\begin{tabular}{ccccc}
\hline $\begin{array}{c}\text { Fishing } \\
\text { gear used }\end{array}$ & $\begin{array}{c}\text { Catch } \\
\text { date }\end{array}$ & $\begin{array}{c}\text { Catch } \\
\text { weight }(\mathrm{kg})\end{array}$ & $\begin{array}{c}\text { Code for } \\
\text { species }\end{array}$ & $\begin{array}{c}\text { Code for } \\
\text { fishing areas }\end{array}$ \\
\hline TAM & $12 / 11 / 99$ & 9.3 & 2299 & D16E8M0 \\
PIB & $13 / 11 / 99$ & 5.09 & 2299 & D16E8UV \\
PIB & $15 / 11 / 99$ & 1.0 & 2299 & D16E8UV \\
PIB & $17 / 11 / 99$ & 1.4 & 2299 & D16E8UV \\
PIB & $19 / 11 / 99$ & 14.8 & 2299 & D16E8UC \\
PIB & $20 / 11 / 99$ & 11.5 & 2299 & D16E8UC \\
PIB & $22 / 11 / 99$ & 7.5 & 2299 & D16E8UV \\
PIB & $23 / 11 / 99$ & 1.7 & 2299 & D16E8UV \\
PIB & $24 / 11 / 99$ & 1.2 & 2299 & D16E8UV \\
TAM & $25 / 11 / 99$ & 7.09 & 2299 & D16E8M2 \\
TAM & $25 / 11 / 99$ & 5.3 & 2299 & D16E8M0 \\
TAM & $27 / 11 / 99$ & 4.5 & 2299 & D16E8M1 \\
TAM & $30 / 11 / 99$ & 3.8 & 2299 & D16E8M0 \\
TAM & $1 / 12 / 99$ & 0.5 & 2299 & D16E8M0 \\
PIB & $4 / 12 / 99$ & 0.8 & 2299 & D16E8UV \\
PIB & $5 / 12 / 99$ & 1.5 & 2299 & D16E8UV \\
\hline
\end{tabular}

Two samples are taken simultaneously at 1 and $4 \mathrm{~m}$ depth respectively. Thirty minutes are necessary to sample the entire width of the river and this allows a maximum of 8 sampling cycles, 24 transects and 48 samples per night. For each sample, glass eels are counted and weighted and their density (biomass in gram per $100 \mathrm{~m}^{3}$ of filtered water) is calculated. The sampling protocol is detailed in De Casamajor et al. (1999). Thus, 54 scientific surveys have been made, at night, from 1998 to 2005 during 6 fishing seasons. They yielded 2592 observations on glass eel densities at two depth strata (1 and $4 \mathrm{~m}$ ) of the water column (Annex).

\subsubsection{Reported catches}

Each fisher fills up a logbook indicating for each trip the catch (in weight), the gear used and the fishing area. These data are stored in a central database at Ifremer and can be used to determine the total catch per day, the mean catch per trip or per gear, and their fluctuations during the fishing season (Table 1). The data used covered the period 1998-2005.

Data are then used to calculate the daily catches of glass eel (Table 2) from the marine professional fisheries in the estuary (below and above Urt, Fig. 2) .

\subsubsection{Hydrodynamic parameters}

Physical and environmental data (tide coefficient, river flow, turbidity and lunar phases) were also collected (Table 2) to characterize the catchability of glass eels as these factors play a major role on the glass eel behavior in the estuary. 
Table 2. Example of hydrodynamic data collected during the scientific surveys associated to reported catches.

\begin{tabular}{ccccccc}
\hline $\begin{array}{c}\text { Date } \\
\text { of survey }\end{array}$ & $\begin{array}{c}\text { Reported } \\
\text { catches }(\mathrm{kg})\end{array}$ & $\begin{array}{c}\text { Moon } \\
\text { phase }\end{array}$ & $\begin{array}{c}\text { Tide } \\
\text { coef. }\end{array}$ & $\begin{array}{c}\text { Turbidity } \\
(\mathrm{NTU})\end{array}$ & $\begin{array}{c}\text { Temp } \\
\left({ }^{\circ} \mathrm{C}\right)\end{array}$ & $\begin{array}{c}\text { River flow } \\
\left(\mathrm{m}^{3} \mathrm{~s}^{-1}\right)\end{array}$ \\
\hline $12 / 01 / 1999$ & 6.0 & NM & 40 & 2.2 & 6.7 & 403.5 \\
$28 / 01 / 1999$ & 4.5 & FM & 66 & 29.8 & 8.7 & 745.9 \\
$09 / 12 / 1999$ & 36.8 & NM & 78 & 3.8 & 7.4 & 142.3 \\
$22 / 12 / 1999$ & 21.2 & FM & 100 & 28.0 & 7.3 & 440.6 \\
$05 / 01 / 2000$ & 77.3 & NM & 71 & 17.7 & 8.3 & 288.8 \\
$09 / 01 / 2000$ & 12.6 & NM & 78 & 9.9 & 7.9 & 206.8 \\
$12 / 01 / 2000$ & 8.8 & FQ & 65 & 8.3 & 8.3 & 192.0 \\
$10 / 01 / 2001$ & 11.5 & NM & 94 & 82.5 & 8.3 & 674.5 \\
$12 / 01 / 2001$ & 18.1 & NM & 104 & 36.0 & 8.7 & 511.1 \\
$26 / 01 / 2001$ & 45.9 & NM & 79 & 21.0 & 10.0 & 500.5 \\
$03 / 01 / 2003$ & 30.4 & NM & 88 & 83.9 & 11.3 & 784.7 \\
$22 / 01 / 2003$ & 2.6 & LQ & 86 & 24.9 & 8.7 & 362.7 \\
$09 / 11 / 2004$ & 10.3 & NM & 65 & 10.0 & 12.3 & 117.12 \\
$18 / 11 / 2004$ & 33.8 & FQ & 55 & 6.0 & 8.5 & 120.6 \\
$14 / 12 / 2004$ & 17.6 & NM & 93 & 9.0 & 9.0 & 94.6 \\
\hline
\end{tabular}

Water temperature is recorded from an automatic probe (accuracy $0.1{ }^{\circ} \mathrm{C}$ ) lying $2 \mathrm{~m}$ underwater at $20 \mathrm{~km}$ from the mouth. Turbidity is estimated from a turbidimeter (Aanderaa type 3712) using an infrared light to measure turbidity between 0 and 500 NTU with a $2 \%$ accuracy. The moon phase is a qualitative variable with four categories corresponding to: new moon (NM), full moon (FM), first quarter (FQ) and last quarter (LQ). The tide coefficient is read from a tide table and the river flow is obtained from the French gauging station network.

\subsection{Methods of estimation}

The process of estimation of the migration and fishery parameters in the push scoopnet fishery involves different steps are summarized (Fig. 3).

\subsubsection{Estimation of nocturnal migrating biomass and exploitation rate}

Let $R$ be the river section at the sampling site. For simplification, we did not consider the variation of the water level during the night flood tide at the sites and used an average value of the depth and the width. According to Stevens and Urquhart (2000), the total biomass for a given period $\left[t_{1}, t_{2}\right]$ passing through the area $R$ (in $\mathrm{m}^{2}$ ) is obtained by adding instantaneous biomass integrated over the entire water column of the river section $R$ and over the whole duration of the flood tide. The total biomass migrating every night through the surveyed area is thus defined as:

$$
B(R)=\int_{R} \int_{t_{1}}^{t_{2}} B_{s}(t) \mathrm{d} t \mathrm{~d} s \quad \text { with } \quad B_{s}(t)=d_{s}(t) \times v_{s}(t)
$$

where $B_{s}(t)$ is the biomass of glass eels at point $s \in R$ and at time $t \in\left[t_{1}, t_{2}\right], d_{s}(t)$ is the glass eels density and $v_{s}(t)$ the current speed.

The functional form $B_{s}(t)$ for each term of this product was determined using statistical models based on in situ measurements and a priori pieces of knowledge (Bru et al. 2006).

\subsubsection{A predictive statistical model for the exploitation rate}

The data used to predict the nocturnal rate of exploitation for every fishing day of the season are:

- Daily catches of glass eels from the professional marine fisheries in the estuary (below the Urt bridge, Fig. 2, Table 1).

- Estimated nocturnal biomass of glass eels during a rising tide at night. From the data base of 54 surveys, 22 (41\%) were removed because they corresponded to: $(i)$ zero catches or no fishing effort in the push scoopnet fishery; (ii) daily fishing effort below 5 boats, i.e. below the minimum number considered necessary to exploit efficiently the fishing area. As a result, the working data base was reduced at 32 lines (Annex).

- The nocturnal rates $(\%)$ of exploitation calculated using the nocturnal biomass estimates during the survey nights and the catches taken during the same night (see Sect. 2.2.1 and Annex)

- Physical and environmental data (tide coefficient, river flow, turbidity and lunar phases) were also collected to characterize the catchability of glass eels (Table 2).

The statistical model developed to predict the rates of exploitation relates the rates estimated during surveyed nights and the coded environmental parameters affecting fishing efficiency. The coding of environmental variables was elaborated to take into account some threshold effects, the variability of point values having less importance for the migration pattern than the crossing of these thresholds. For turbidity, the definition of thresholds is based on experimental studies (Bardonnet et al. 2005) or in situ observations (De Casamajor et al. 1999; Prouzet 2002). For river flow and tide coefficients, the modalities are defined using a one-dimensional hydrodynamic model which, from a well-balanced distribution of tide coefficients, allows classifying the values of river flow according to whether or not there is propagation of the dynamic tide through the estuary and hence migration. The thresholds used respectively for turbidity, tide and river flow are as follows:

- TurbCod: set to 1 if $<13$ NTU and 2 otherwise.

- TideCod: set to 1 if $<60 ; 3$ if $>86$; and 2 otherwise.

- FlowCod: set to 1 if $<250 \mathrm{~m}^{3} \mathrm{~s}^{-1} ; 3$ if $>600 \mathrm{~m}^{3} \mathrm{~s}^{-1}$; and 2 otherwise.

The dataset (Annex) allows defining a statistical model connecting a predicted variable (the daily rate of exploitation) and a set of explanatory variables (daily catches, estimated nocturnal exploitation rates and hydrodynamic conditions for the same day). The selected model is a generalized linear model with a Gamma distribution (commonly used for a continuous dependent variable with a positive range) with an inverse link function (Chambers and Hastie 1992). 


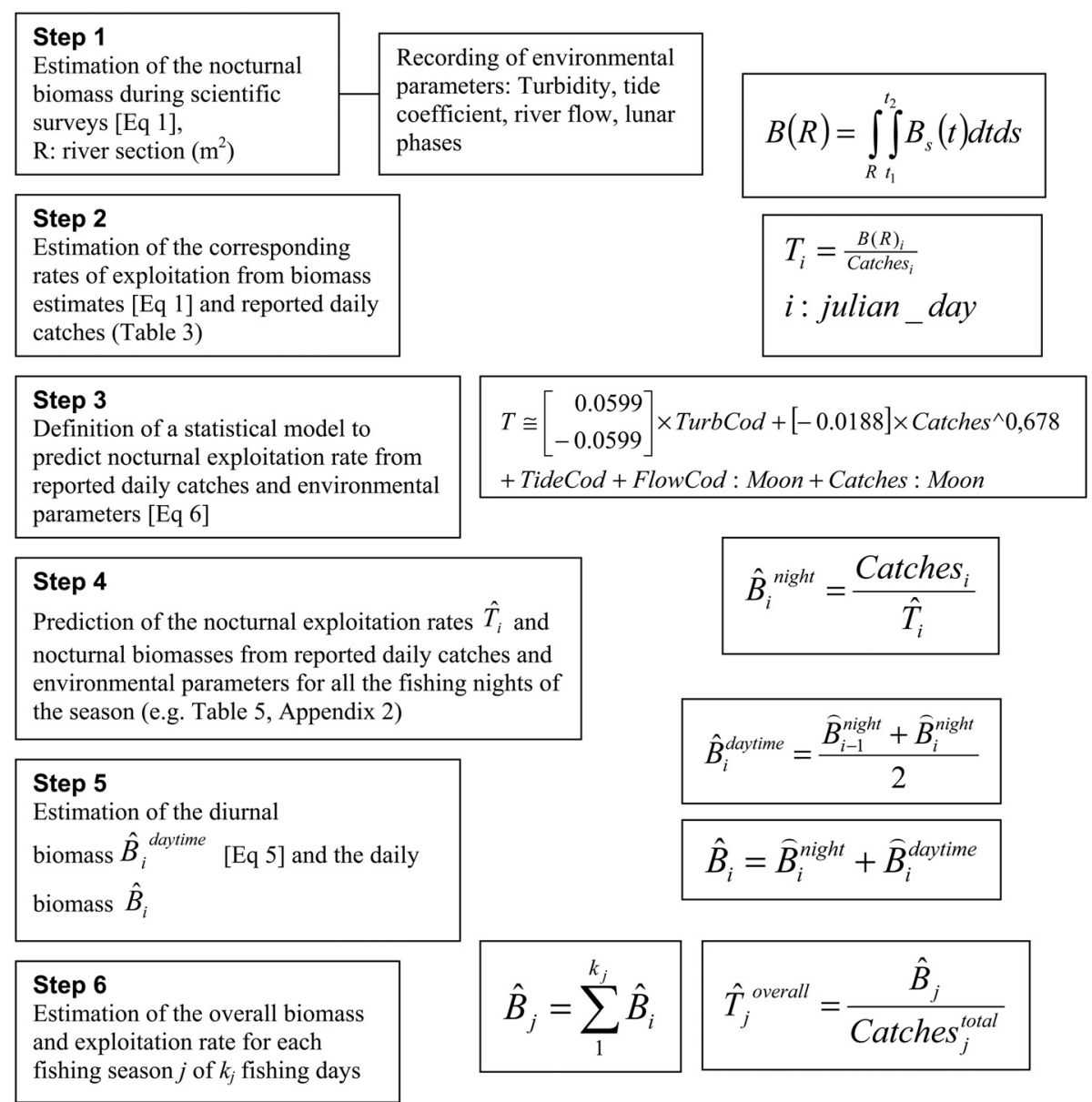

Fig. 3. Main steps of calculation to estimate glass eel biomass.

Table 3. Prediction of nocturnal exploitation rate (\%) and biomass (kg) from hydrodynamic and catch data (e.g. the 2002-2003 fishing season).

\begin{tabular}{ccccccccccc}
\hline $\begin{array}{c}\text { Fishing } \\
\text { date }\end{array}$ & $\begin{array}{c}\text { Reported } \\
\text { catches }(\mathrm{kg})\end{array}$ & Tide coef & $\begin{array}{c}\text { Flow } \\
\left(\mathrm{m}^{3} \mathrm{~s}^{-1}\right)\end{array}$ & Turbidity (NTU) & TideCod & TurbCod & $\begin{array}{c}\text { FlowCod } \\
\text { Moon } \\
\text { Phase }\end{array}$ & $\begin{array}{c}\text { Tpredict } \\
(\%)\end{array}$ & $\begin{array}{c}\text { Night } \\
\text { biomass }(\mathrm{kg})\end{array}$ \\
\hline $03 / 11 / 2002$ & 0.2 & 98 & 142 & 7 & 3 & 1 & 1 & NM & 1.35 & 14.82 \\
$04 / 11 / 2002$ & 1.0 & 108 & 180 & 7 & 3 & 1 & 1 & NM & 2.48 & 40.36 \\
$05 / 11 / 2002$ & 2.2 & 112 & 186 & 7 & 3 & 1 & 1 & NM & 3.34 & 65.94 \\
$06 / 11 / 2002$ & 2.0 & 108 & 167 & 7 & 3 & 1 & 1 & NM & 3.22 & 62.14 \\
$07 / 11 / 2002$ & 1.6 & 99 & 642 & 50 & 3 & 2 & 3 & NM & 14.82 & 10.8 \\
$08 / 11 / 2002$ & 1.3 & 85 & 661 & 54 & 2 & 2 & 3 & NM & 9.11 & 14.28 \\
$10 / 11 / 2002$ & 1.2 & 53 & 1655 & 103 & 1 & 2 & 3 & FQ & 7.58 & 15.83 \\
$21 / 11 / 2002$ & 0.3 & 81 & 271 & 10 & 2 & 1 & 2 & FM & 3.57 & 8.4 \\
$22 / 11 / 2002$ & 0.8 & 78 & 242 & 9 & 2 & 1 & 1 & FM & 1.62 & 49.45 \\
$25 / 11 / 2002$ & 0.1 & 56 & 234 & 9 & 1 & 1 & 1 & LQ & 1.07 & 9.36 \\
$03 / 12 / 2002$ & 1.6 & 97 & 1840 & 156 & 3 & 2 & 3 & NM & 14.82 & 10.8 \\
$04 / 12 / 2002$ & 1.0 & 100 & 1297 & 418 & 3 & 2 & 3 & NM & 12.41 & 8.06 \\
$05 / 12 / 2002$ & 3.6 & 98 & 1427 & 590 & 3 & 2 & 3 & NM & 20.13 & 17.89 \\
$06 / 12 / 2002$ & 16.1 & 92 & 1039 & 198 & 3 & 2 & 3 & NM & 35.43 & 45.45 \\
$07 / 12 / 2002$ & 18.4 & 82 & 793 & 88 & 2 & 2 & 3 & NM & 24.76 & 74.33 \\
\hline
\end{tabular}




\subsubsection{Prediction of nocturnal exploitation rate and biomass for every night of the fishing season}

The nocturnal rates of exploitation and biomass for everyday of the fishing season are predicted from the statistical model developed above, using the observed hydrodynamic and catch data (Table 3, example for a part of the 2002-2003 season).

The prediction generated a number of values which were either impossible or incompatible with available a priori expert knowledge on the fishery or fish behavior. As a consequence the time series of predicted exploitation rates and biomass were cleaned, eliminating the dates corresponding to any of the following cases: $(i)$ Nonsensical exploitation rates, either negative or $>100 \%$; ( ii) Low rates of exploitation $(<1.5 \%)$ associated with a high catch per day $(>100 \mathrm{~kg})$ leading to large biomass estimates, considered as impossible by experts in this fishery; and (iii) Periods with heavy floods (flow $>600 \mathrm{~m}^{3} \mathrm{~s}^{-1}$ ) and low tide coefficient $(<60)$ as these conditions prevent the proper sampling of the water mass and keep glass eels out of the water column, close to the bottom and banks, interfering strongly with their upstream migration (Prouzet e al. 2009). In the example shown in Table 3, only 9\% of the estimates needed to be discarded.

The predicted nocturnal biomass $\hat{B}_{i}^{\text {night }}$ migrating through the estuary each day $i$ at night is obtained directly by dividing the reported capture $C_{i}$ (obtained at night) by the predicted nocturnal rate of exploitation $\hat{T}_{i}$ for that day $i$ with an associated standard error $(S E)$ :

$$
\frac{S E\left(\hat{T}_{i}\right) \times C_{i}}{\hat{T}_{i}^{2}} .
$$

The computation of the variability of the estimate $\hat{B}_{i}^{\text {night }}$ takes into account temporal dependences between observations from one night to another in using the autocorrelation between the values of biomass of 2 consecutive nights. So, the autocorrelation between the estimated values of glass eels biomass migrating by night are estimated with an autoregressive process of order 1 (Hamilton 1994):

$$
B_{i}^{\text {night }}=\phi B_{i-1}^{\text {night }}+\varepsilon_{i}
$$

where $i=1, \ldots, n$ with $\left\{\varepsilon_{i}\right\}$ is a white noise, $\phi$ is the autocorrelation coefficient.

The time series so established is incomplete as there are no estimates of nocturnal migrating biomass for non-fishing days, such as the week-ends, during which fishing is prohibited, and the days for which the results of the computation were aberrant and hence eliminated. An interpolation of missing values of nocturnal migrating biomass $\left(\hat{B}_{i}^{\text {night }}\right)$ may be made from a smoothing by the "Gaussian kernels" (Fan and Yao 2005). The smoothing window is the number of days during which: (i) a run of glass eels is available to the professional fisheries in the maritime zone (lower rectangle, Fig. 2) and (ii) the flood and tide coefficient allow the rising tide to progress through the estuary (Prouzet et al. 2008). This process provides an estimate of the missing biomass values, if the series of consecutive missing values is not too large. This smoothing represents one implementation of a path of a stochastic process depicting the glass eels biomass migrating during the night every day $i$ of the fishing season.

\subsubsection{Overall seasonal migration biomass and exploitation rate}

The sum of the predicted nocturnal migrating biomass $\hat{B}_{i}^{\text {night }}$ over an entire fishing season represents an estimate of the total seasonal biomass $\hat{B}^{\text {night }}$ that has immigrated that season during night flood tides, i.e. the total nocturnal glass eel recruitment. If we consider the $\hat{B}_{i}^{\text {night }}$ values without error, we can estimate the variability of $\hat{B}^{\text {night }}$ as follows:

$$
\begin{aligned}
V\left(\hat{B}^{\mathrm{night}}\right)= & V\left(\sum_{i=1}^{n} \hat{B}_{i}^{\mathrm{night}}\right)=\sum_{i=1}^{n} V\left(\hat{B}_{i}^{\mathrm{night}}\right) \\
& +2 \times \frac{\phi}{1-\phi^{2}} \times(n-1) \times \sigma^{2}
\end{aligned}
$$

where $\sigma^{2}$ is the variance of the white noise from the $\operatorname{AR}(1)$ model. This variance is evaluated (for $|\phi|<1$ ) by: $\sigma^{2}=$ $\left(1-\phi^{2}\right) \times V\left(\hat{B}_{i}^{\text {night }}\right)$.

\subsubsection{Recruitment and overall rate of exploitation}

The nocturnal migrating biomass and exploitation rates estimates obtained in the previous sections correspond to the glass eels runs moving upstream during the night, for a given fishing day or season. It is known, however, that an upstream migration of glass eels occurs also during the rising tides in day time (diurnal migration), close to the bottom (Adam et al. 2008a; Prouzet et al. 2008). As a consequence, the total daily biomass migrating inside the estuary is the sum of the diurnal and nocturnal biomasses that cross the survey area. As during the day, there is no fishing, and scientific sampling of glass eel densities is impractical, the biomass involved in diurnal migration must be obtained by a simple arithmetic average of two successive nocturnal biomass estimates as explained below. This procedure assumes that the recruitment process at the mouth is a continous function of time, modulated in the estuary, by the dynamic tides and partly demodulated by local hydrodynamic conditions in the first $10 \mathrm{~km}$ of estuary.

The beginning and the end of the first fishing zone are located approximatively at 10 and $20 \mathrm{~km}$ from the mouth of the river rea (lower rectangle, Fig. 2). The studies done on the speed of migration of glass eel through the Adour estuary (Prouzet et al. 2009) estimated that the time necessary to the glass eel to travel $20 \mathrm{~km}$ was about 2 days. As a consequence, a run of glass eel entering the river during day-time can be exploited, at least partly, during the following day, at night, in the scoopnet fishing area. A schematic diagram of the progression of different runs of glass eel in the estuary explains why we can detect the abundance of glass eel run that entered the river during day-time, around two nights later, in the fishing area (Fig. 4).

For example, a glass eel run (number 3 ) that enters at the mouth the day 2 during day time, reaches the fishing area at 


\begin{tabular}{|l|c|c|c|c|c|}
\hline & $\begin{array}{c}\text { Flood } \\
\text { tide }\end{array}$ & $\begin{array}{c}0 \text { to } 5 \\
\mathrm{~km}\end{array}$ & $\begin{array}{c}5 \text { to } 10 \\
\mathrm{~km}\end{array}$ & $\begin{array}{c}10 \text { to } 15 \\
\mathrm{~km}\end{array}$ & $\begin{array}{c}15 \text { to } \\
20 \mathrm{~km}\end{array}$ \\
\hline Day 1 & Daytime & 1 & & & \\
\cline { 2 - 6 } & Night & 2 & 1 & & \\
\hline Day 2 & Daytime & $\mathbf{3}$ & 2 & 1 & \\
\cline { 2 - 6 } & Night & 4 & $\mathbf{3}$ & 2 & 1 \\
\hline Day 3 & Daytime & 5 & 4 & $\mathbf{3}$ & 2 \\
\cline { 2 - 6 } & Night & 6 & 5 & 4 & $\mathbf{3}$ \\
\hline & & & & \multicolumn{2}{|c|}{ Fishing area } \\
\hline
\end{tabular}

Fig. 4. Scheme of the propagation of glass eels runs (numbered 1 to 6 ) in time and space.

the end of the night of day 2 and is fully available to fishing the day 3 during the night (Fig. 4).

The light grey cells materialize the progression of a run. The dark vertical line represents approximately the position of the sampling station

For a given day $i$, the daily biomass is therefore:

$$
\hat{B}_{i}=\hat{B}_{i}^{\text {night }}+\hat{B}_{i}^{\text {daytime }} \quad \text { with } \quad \hat{B}_{i}^{\text {daytime }}=\frac{\hat{B}_{i-1}^{\text {night }}+\hat{B}_{i}^{\text {night }}}{2} .
$$

This computation can be used for day 2 to $n$ and we suppose that $\hat{B}_{1}=\hat{B}_{1}^{\text {night }}$ for the first day of the period.

So, we can define the estimate of the total biomass $\hat{B}$, passing through the scientific station during the entire fishing season, as the sum of the daily $\hat{B}_{i}$ values predicted for each day of the season. The overall rate of exploitation of the glass eels by the push and hand scoopnet fisheries is estimated as the ratio between the total reported catches of glass eel made in the catchments during the fishing season by both fisheries and the estimate $\hat{B}$ of the total estuarine recruitment biomass (step 6, Fig. 3).

\section{Results}

\subsection{Estimates of the glass eel biomass during a rising tide by night}

The differences in night biomasses estimated by scientific surveys, during 6 different fishing seasons between 1998 and 2004, show a high variation among fishing seasons (Fig. 5). The highest values for night biomass were recorded during the 1999/2000 fishing season corresponding to the highest seasonal catches of the series (Table 5).

\subsection{Relationships between nocturnal rate of exploitation, hydrodynamic conditions and catch}

For the Adour estuary, the model used links the nocturnal rate of exploitation $(T)$ to explanatory variables related to turbidity (TurbCod), tide (TideCod) and river flow (FlowCod), as defined previously), as well as professional Catches (in $\mathrm{kg}$ )
Table 4. Deviance table for the model defined by Eq. (6) ( $d f$ : degree of freedom)

\begin{tabular}{lccccc}
\hline & $d f$ & Deviance & Residual $d f$ & $F$ value & $\operatorname{Pr}(F)$ \\
\hline NULL & - & - & 31 & - & - \\
TurbCod & 1 & 9.572 & 30 & 18.75 & 0.001 \\
Catches^0.678 & 1 & 3.185 & 29 & 6.24 & 0.024 \\
TideCod & 2 & 0.939 & 27 & 0.92 & 0.419 \\
FlowCod:Moon & 8 & 7.044 & 19 & 1.72 & 0.168 \\
Catches:Moon & 3 & 1.295 & 16 & 0.85 & 0.489 \\
\hline
\end{tabular}

and Moon phase. It is defined as follows ${ }^{3}$ :

$$
\begin{aligned}
T \cong & {\left[\begin{array}{r}
0.0599 \\
-0.0599
\end{array}\right] \times \text { TurbCod }+[-0.0188] \times \text { Catches }^{\wedge} 0,678 } \\
& + \text { TideCod }+(\text { FlowCod:Moon })+(\text { Catches:Moon })
\end{aligned}
$$

where,

- (FlowCod: Moon), order 1 interaction between flow $\left(\mathrm{m}^{3} \mathrm{~s}^{-1}\right)$ and lunar phases.

- (Catches: Moon), order 1 interaction between catches $(\mathrm{kg})$ and lunar phases.

As expected, the deviance table (Table 4) shows a very significant effect of the level of turbidity on the value of daily rate of exploitation. The catch level represents a scaling factor (availability of glass eels on the fishing area).

Finally, $90 \%$ of the variability of the rate of exploitation is explained by this model and nearly all the pairs of observations (fitted versus observed) are closed to the first bisecting line.

\subsection{Prediction of the time series of nocturnal biomasses (1998-2005)}

In this section, only the calculations for the 1999/2000 fishing season, considered as the best of the series, are illustrated. The time series of predicted glass eels biomasses migrating every night is given (Fig. 6). The curve describes the dayto-day variations of the predicted nocturnal biomasses after smoothing of the series of values calculated using results of Equation (6). The black dots indicate the values of the nocturnal biomasses obtained from scientific surveys which appear to be in good agreement with the values predicted by the model. Although peaks up to $6 \mathrm{t}$ per night have been observed, the biomass of glass eels migrating through the lower estuary, during the 1999-2000 fishing season has been generally lower than $2 \mathrm{t}$ per night. The autocorrelation coefficient between two consecutive nocturnal biomasses is equal to $0.18^{4}$.

The total biomass of glass eels migrating by night during the $1999-2000$ fishing season $\left(\hat{B}^{\text {night }}=\right.$ the sum of the $\left.\hat{B}_{i}^{\text {night }}\right)$ is

\footnotetext{
${ }^{3}$ Coefficients between square brackets (Eq. (6)) are given only for explanatory variables with significant effects. As the link function is inverse, a negative coefficient means a positive effect on the value of the predictive variable, e.g. turbidity higher than 13 NTU (category 2 ) is associated to high exploitation rate.

4 The variance of the white noise is supposed to be equal to the variance of the stochastic process: $\left(1-\phi^{2}=0.96 \approx 1\right.$ and $\frac{\phi}{1-\phi^{2}}=$ $0.18)$.
} 

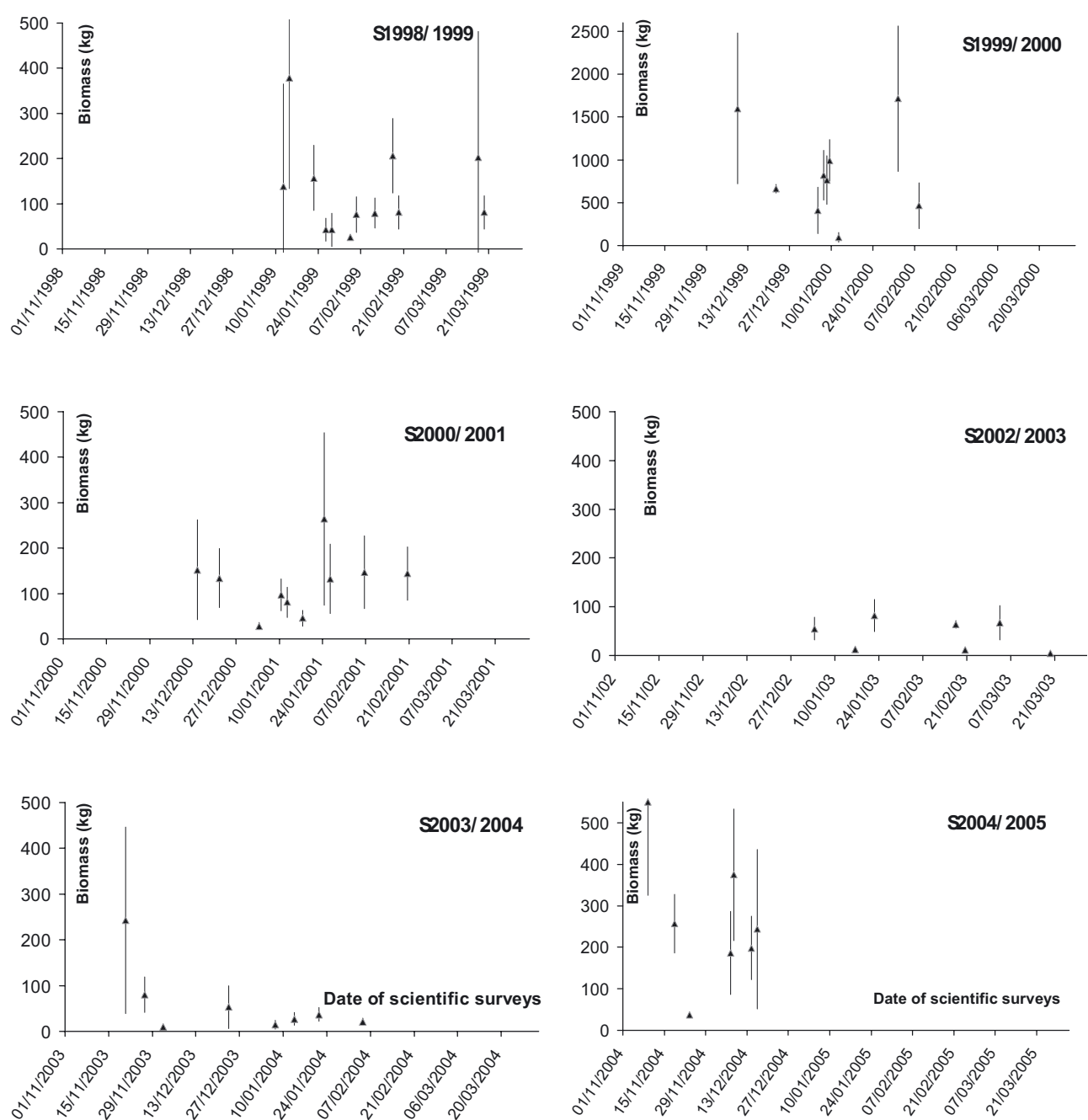

Fig. 5. Nocturnal biomass estimates (and standard error) from scientific surveys during 6 fishing seasons (a different scale for $1999 / 2000$ biomass).

estimated at $96.9 \mathrm{t}$, with a standard error of $6.7 \mathrm{t}(\mathrm{Eq}$. (4)) and hence a confidence interval at $95 \%$ of its "true" value ranging from 83.7 to $110.1 \mathrm{t}$.

For 1998-2005, the variation of the nocturnal biomass is estimated from scientific surveys with the same methodology (Fig. 7). The precision of the biomass estimates ranged between 6 and $14 \%$. The maximum value of the series is $96.9 \mathrm{t}$ in 1999/2000, and the minimum $2.4 \mathrm{t}$ in 2002/2003.

\subsection{Estimates of overall recruitment and exploitation rate: 1998-2005}

The predicted glass eel biomasses migrating upstream with a rising tide during daytime (diurnal biomass) are estimated, see Equation (5). Then, these are added to the nocturnal biomass to provide an estimate of the total glass eel recruitment that enters the estuary daily and during the entire fishing season.

Table 5 gives the details on: $(A)$ length of the time series of catches used for calculations; $(B)$ recorded catches of the push scoopnet fishery in the lower part of the estuary (inside the
20 first km from the mouth, Fig. 2); (C) total recorded catches from hand and push scoopnet fisheries ; $(D)$ total recruitment estimated as the sum of the diurnal and nocturnal biomasses migrating during the two rising tides everyday, covering the entire migration daily cycle; $(E)$ overall rate of exploitation obtained from the ratio between total recorded catches and total recruitment; $(F)$ mean level of recruitment per day during the fishing season. This indicator can be used for comparison of mean level of recruitment among the fishing seasons.

The index in column $\mathrm{F}$ gives an idea of the fluctuation of the overall level of recruitment from year to year from a quantitative point of view and indicates that, during the last four years of the series, we have had three years below the median $(328 \mathrm{~kg})$ and a ratio of 26 between the minimum and the maximum mean daily recruitment.

\section{Discussion}

\subsection{Characteristics of the model}

The environmental variables were coded in categories to take into account the existence of thresholds in the 
Table 5. Data and results of calculations for the period 1998-2005.

\begin{tabular}{|c|c|c|c|c|c|c|}
\hline Column & A & $\mathrm{B}$ & $\mathrm{C}$ & $\mathrm{D}$ & $\mathrm{E}=\mathrm{C} / \mathrm{D}$ & $\mathrm{F}=\mathrm{D} / \mathrm{A}$ \\
\hline Fishing season & 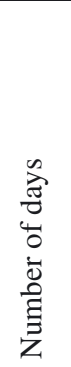 & 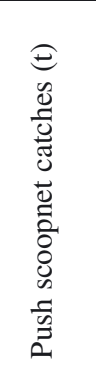 & 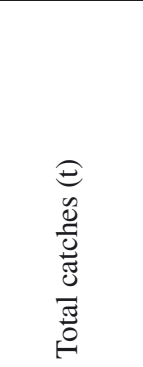 & 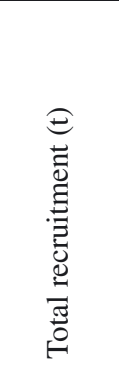 & 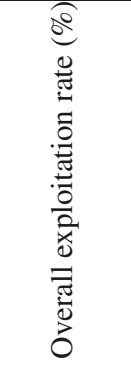 & 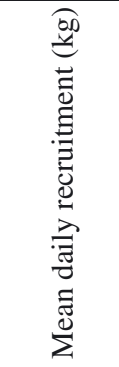 \\
\hline 9 Nov. 1998-24 Feb. 1999 & 108 & 1.655 & $\sim 6.000$ & 50.393 & 12.0 & 467 \\
\hline 1 Nov. 1999-14 Feb. 2000 & 106 & 4.579 & $\sim 15.000$ & 181.354 & 8.3 & 1711 \\
\hline 1 Nov. 2000-19 Mar. 2001 & 132 & 1.446 & $\sim 4.000$ & 31.430 & 12.7 & 238 \\
\hline 12 Nov. 2001- 5 Mar. 2002 & 100 & 0.770 & $\sim 6.000$ & 41.777 & 14.3 & 418 \\
\hline 3 Dec. 2002-13 Mar. 2003 & 75 & 0.388 & $\sim 1.200$ & 4.868 & 25.0 & 65 \\
\hline 13 Nov. 2003-23 Feb. 2004 & 94 & 1.093 & 2.969 & 17.239 & 17.2 & 183 \\
\hline 2 Nov.2004-9 Mar. 2005 & 128 & 1.398 & 7.183 & 59.109 & 12.2 & 462 \\
\hline 1 Nov.2005-17 Mar. 2006 & 126 & 0.686 & 3.531 & 14.984 & 23.6 & 119 \\
\hline Average 1998-2005 & 108 & 1.502 & 5.735 & 50.144 & 15.7 & 458 \\
\hline Median 1998-2005 & 107 & 1.245 & 5.000 & 36.604 & 13.5 & 328 \\
\hline
\end{tabular}

relationships as mentioned by De Casamajor et al. (1999), Prouzet et al. (2003) or Bardonnet et al. (2005) for the level of turbidity and by Creutzberg (1961), Prouzet et al. (2003), Jellyman et al. (2009) for the levels of the flow rate and tide coefficient. This approach increased the degrees of freedom but was considered necessary to better represent the phenomena under study. Furthermore, the use of the generalized linear model (GLM) assumes the choice of a single link function applying to the combination of all the explanatory variables. Therefore, in order to avoid a complicated mathematical writing of the GLM, involving threshold effects for some variables and others types of links for others, it was decided to code all of them. This sort of modeling can rapidly face over-fitting problems because it increases the number of parameters if we try to fit exactly the data with insufficient information.

It is also rather tricky to discuss the significance of the terms of the model from the statistical tests supplied by the automated statistical methods provided in the software when the data is so sparse. For this reason, the terms introduced into the proposed model were not supported by means of a statistical procedure such as AIC (Akaike's information criterion).

We chose to produce a general model applicable to any estuary by integrating all the variables supposed to influence the exploitation rate in different hydrodynamic environments. For example, on the Loire estuary, the turbidity is not a significant factor because waters are always turbid and, as a consequence, the tide coefficient has an overriding effect on exploitation rate (http://www.ifremer.fr/indicang/ boite-bassins-versants/pdf/rapport-saison-bv-loire.pdf).

The fact that adding terms that might not be significant increased the percentage of variance explained by the model was thoroughly discussed between the statistician and the biologist. It was finally agreed to define a model taken into account as much as possible of the biological information available in different rivers where the migratory behavior of glass eels was studied during the scientific surveys of the INDICANG project (Prouzet et al. 2008). The confidence intervals of the biomass estimates are just given to provide an idea on their variability in the working conditions. The true precision of the estimates was not discussed because it is clear that all the possible sources of variability were not taken into account, as usual in these field evaluations of abundance.

\subsection{Consistency of predicted biomass}

The seasonal biomass predicted for the 1999-2000 fishing season is much higher than the others (Fig. 7) and more than 3 times higher than the time series average (Table 5). A question to consider is whether these predictions are coherent with the level of abundance of the glass eel run deduced from knowledge on the catches and fishing effort.

Seven predicted values (see Methods Sect. 2.2) were much higher than $2 \mathrm{t}$ of biomass per night, the maximum level recorded during our scientific surveys (Figs. 5 and $6-$ S1999/2000). Moreover, a biomass of $4 \mathrm{t}$ per night is roughly equivalent to a density of glass eels of $0.53 \mathrm{~g}^{5} \mathrm{~m}^{-3}$ of water flowing through the fishing area. Taking the average weight of the glass eel as $0.35 \mathrm{~g}^{6}$, this density is equal to 150 ind. per $100 \mathrm{~m}^{3}$. This level corresponds to the maximum ever observed during any of the scientific surveys ${ }^{7}$. For a whole scientific survey, the mean of the observed densities in any given night has

\footnotetext{
5 With a river width of $210 \mathrm{~m}$, a depth of $5 \mathrm{~m}$, and an average current speed of $0.5 \mathrm{~m} \mathrm{~s}^{-1}$ during 4 hours, the volume of water flowing during a mean rising tide is $7560000 \mathrm{~m}^{3}$.

${ }^{6}$ As measured during the scientific surveys by Prouzet coord. (2003)

7 Scientific survey made on December $22^{\text {nd }}, 1999$, Prouzet coord. (2003, 105, Fig. 56).
} 


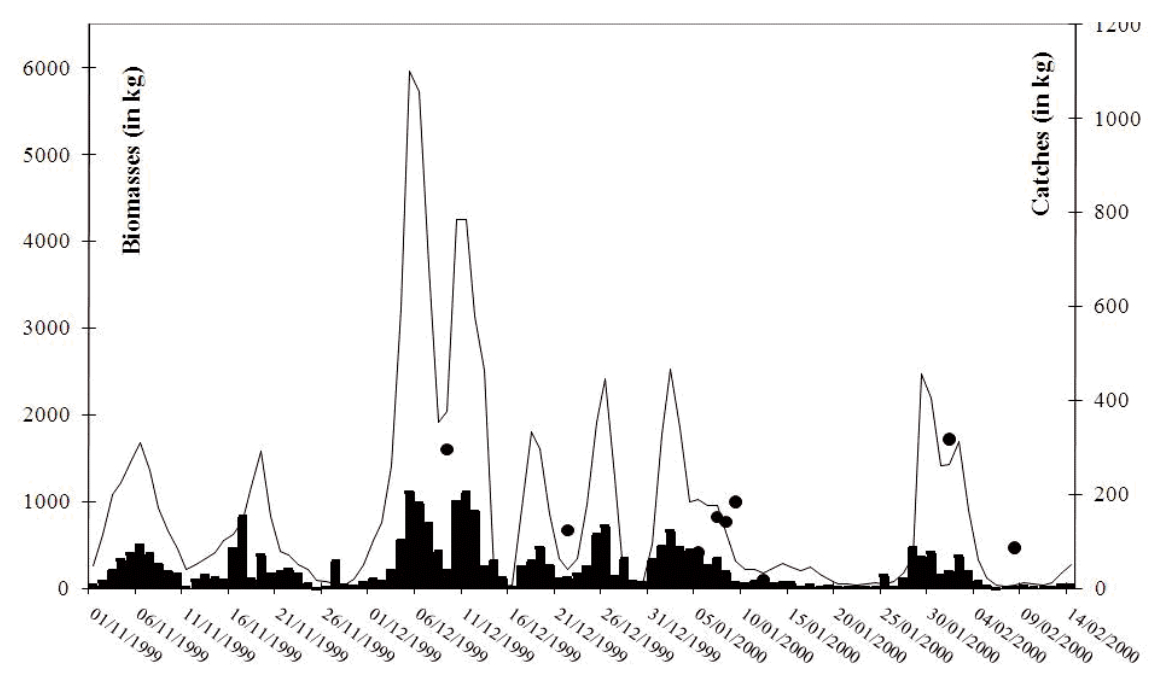

Fig. 6. Fluctuations of reported catches (black blocks) and nocturnal biomasses observed (during surveys, black circles) and predicted (smoothed values, black line).

been at best $10 \mathrm{~g}$ per $100 \mathrm{~m}^{3}$ equivalent to 30 individuals per $100 \mathrm{~m}^{3}$ (e.g. December 22, 1999, Fig. 5, S1999/2000).

An another way to check the validity of these very high predictions is to calculate what theoretical level of catches, a glass eel density of $0.53 \mathrm{~g} \mathrm{~m}^{-3}$ would produce, considering the characteristics of the scoopnet fishery as described previously and the volume filtered in one night by a fishing boat (22 000 to $32000 \mathrm{~m}^{3}$ depending on horse power). Such a density would be equivalent to a theoretical catch/boat/night of $11.6-17.0 \mathrm{~kg}$. The maximum recorded total catch per day, for the whole fleet, during the 1999-2000 fishing season was around $200 \mathrm{~kg}$ (Fig. 6), corresponding in those days to a mean catch per boat around $10 \mathrm{~kg}$ with a maximum close to $20 \mathrm{~kg}$. A predicted biomass of $4 \mathrm{t}$ for one night seems therefore plausible even though it was never observed during the scientific surveys.

However, biomass predictions higher than $4 \mathrm{t}$ per day, as obtained in 1999-2000, seem unlikely with the information available and may indicate a possible underestimation of the exploitation rate by the model in the prevailing environmental conditions resulting in an overestimation of the corresponding biomass.

In estimating the total daily recruitment, we assumed that glass eels entered the river mouth at each rising tide, twice a day. This assumption is supported by observations made on several turbid water estuaries as the Gironde estuary (Cantrelle 1981) showing indeed that glass eels can enter the river during daytime (Creutzberg 1961) and that some catches can be made at the surface, close to the mouth. It is also supported by observations made on the Adour river or on the Isle river (Susperregui et al. 2007; Prouzet et al. 2008) showing that glass eels migrate close to the bottom in clear water during daytime. This diurnal migration during flood tide is also observed by Jellyman et al. (2009) for glass eels of two anguillid species in New Zealand.

Another assumption is the non accumulation of different runs of glass eels issued from two (or more) consecutive rising tides. The studies undertaken on the behavior of glass eels in the Adour river (Prouzet 2003; Prouzet et al. 2009) showed

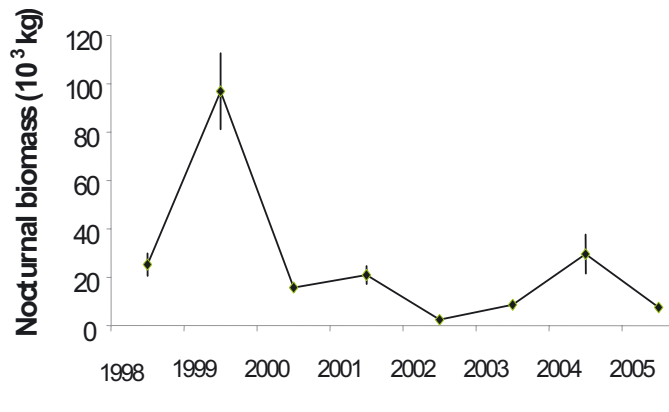

Fshingseason

Fig. 7. Seasonal nocturnal biomass estimates for the period 1998 to 2005.

in normal hydroclimatic conditions when the tide progress through the estuary, that the daily glass eel runs remain distinct (and hence exploited separately), at least in the first $30 \mathrm{~km}$. This may not be the case anymore further up in the Adour river where separate runs may accumulate where the dynamic tide slows down or stops, particularly during periods of floods. In these cases, the hydrological constraints prevent the estimation of the daily biomass. When frequent floods lasting more than 3 days occur during the fishing season, a significant number of days are excluded from the calculations and consequently the seasonal biomasses are underestimated.

\subsection{Level of the exploitation rates and comparison with other estuaries}

The differences in exploitation rates between fishing seasons may partly be due to variations in the hydrodynamic conditions prevailing in each fishing period. In the lower estuary, during long periods without rain, the rate of flow is low and the water is clear. As a consequence, the runs of glass eels migrate upstream at high speed and mainly close to the bottom during daytime and bright nights, outside the layers of the water column sampled by the push scoopnet fishery. On the contrary, 
when several periods of river floods occur, the dynamic tide does not progress in the estuary and the runs of glass eels are slowed down or stopped in the lower estuary where they accumulate. When the tide resumes its ingressions into the estuary, a high density of glass eels is present in the water column, close to the surface because of the high water turbidity after the floods, and their availability for the push scoopnet fishery is maximum.

In the framework of the INDICANG project (Prouzet 2004, http://www.ifremer.fr/indicang/), some studies on fishing intensity (rate of exploitation) have been undertaken in other catchments either in the lower or upper parts of the estuary (Adam et al. 2008a; Susperregui et al. 2007; Prouzet et al. 2007). Results indicate rates ranging from 15 to $20 \%$ in the Loire estuary and 1 to $30 \%$ (depending on highly variable fishing effort) in the Isle River, a tributary of the Dordogne River. These values are much lower, however, than the 88-98\% values observed in 1996-2000 in the Vilaine estuary closed by a dam (Briand et al. 2003; Anonymous 2005).

\section{Conclusion}

The method used here to assess biomasses and exploitation rates can be adapted to different estuaries of different sizes in order to evaluate the state of stocks and assist in their management in the framework of the new European Commission eel regulation (EC 1100/2007, Sept. 18, 2007). Some improvements have to be made in order to better estimate the precision of the daily biomass. In fact, the computation of the precision of $\hat{B}^{\text {night }}$ does not take into account the precision of the estimate of $\hat{B}_{i}^{\text {night }}$ itself. It should be mentioned that the precision of the seasonal biomass estimates of glass eels migrating by night is presently overestimated (i.e. its variance is underestimated). The definition of the true variance is more complex and will be the subject of a future study. Some investigations have already been conducted with different methodologies using resampling techniques to evaluate more accurately the precision of the biomass estimates (Prouzet et al. 2007).

\section{References}

Adam G., Feunteun E., Prouzet P., Rigaud C., 2008a, L'anguille européenne : indicateurs d'abondance et de colonisation. Coll. Savoir-faire, éditions Quae, Versailles.

Adam G., Castelnaud G., Cuende F.-X., Diaz E., Feunteun E., Girard P ., Laffaille P., Lauronce V., Muchiut S., Orroz-Urrizalki I., Prouzet P., Rigaud C., Soulier L., Susperregui N., 2008b, La vie de l'anguille. In: Adam G., Feunteun E., Prouzet P., Rigaud C. (eds.) L'anguille européenne : indicateurs d'abondance et de colonisation. Coll. Savoir-faire, éditions Quae Versailles, pp. 19-41.

Anonymous, 2005, Pêches professionnelles et scientifiques de la civelle en estuaire de Vilaine (Morbihan) : Bilan de la saison de pêche 2004-2005. Rapp. Institution d'Aménagement de la Vilaine http://www.ifremer.fr/indicang/boite-bassins-versants/ pdf/peche-prof-scient-civelles-vilaine-2005.pdf
Bardonnet A., Bolliet V., Belon V., 2005, Recruitment abundance estimation. Role of glass eels (Anguilla anguilla) response to light. J. Exp. Mar. Biol. Ecol. 321, 181-190.

Bolliet V., Labonne J., 2008, Individual patterns of rhythmic swimming activity in Anguilla anguilla glass eels synchronised to water current reversal. J. Exp. Mar. Biol. Ecol. 362, 125-130.

Briand C., Fatin D., Feunteun E., Fontenelle G., 2003, Estuarine and fluvial recruitment of European glass eel in a fished Atlantic estuary. Fish. Manage. Ecol. 10, 377-384.

Bru N., Lejeune M., Prouzet P., 2006, Estimating daily passive fish abundance in an open estuary from sparse data in spatio-temporal sampling: particular case of glass eel flows. Prépublication LMA, Université de Pau http://hal.archives-ouvertes.fr/hal-00221421/fr/

Cantrelle I., 1981, Etude de la migration et de la pêche des civelles (Anguilla anguilla, L.) dans l'estuaire de la Gironde. Thèse $3^{\text {ème }}$ cycle, Univ. Paris VI.

Chambers J.M., Hastie T.J. (eds.), 1992, Statistical models. Wadsworth and Brooks/ Cole.

Creutzberg F., 1961, On the orientation of migrating elvers (Anguilla vulgaris) in a tidal area. Neth. J. Sea Res. 1, 257-338.

Cuende F.-X., Caill-Milly N., Prouzet P., 2002, Site atelier de l'Adour. Contrat PECOSUDE : Caractéristiques des petites pêches côtières et estuariennes de la côte atlantique du sud de l'Europe, $\mathrm{N}^{\circ}$ 99/024.

De Casamajor, M.-N., Bru N., Prouzet P., 1999, Influence de la luminosité nocturne et de la turbidité sur le comportement vertical de migration de la civelle d'anguille (Anguilla anguilla $\mathrm{L}$.) dans l'estuaire de l'Adour. Bull. Fr. Pêche Piscic. 355, 327-347.

Edeline E., Dufour S., Elie P., 2005. Role of glass eel salinity preference in the control of habitat selection and growth plasticity in Anguilla anguilla. Mar. Ecol. Prog. Ser. 304, 191-199.

Edeline E., Lambert P., Rigaud C., Elie P., 2006. Effects of body condition and water temperature on Anguilla anguilla glass eel migratory behavior. J. Exp. Mar. Biol. Ecol. 331, 217-225.

Fan J., Yao Q., 2005, Nonlinear time series: nonparametric and parametric methods. Springer.

Hamilton J.D., 1994, Time series analysis. Princeton University Press.

Jellyman D.J., Booker D.J., Watene E., 2009, Recruitment of Anguilla spp. glass eels in the Waikato River, New Zealand. Evidence of declining migrations? J. Fish Biol. 74, 2014-2033.

Lissardy M., De Casamajor M.-N., Sanchez F., Prouzet P., Morandeau G., Cuende F.-X., 2005, Caractérisation et abondance des captures professionnelles estuariennes dans l'estuaire de l'Adour en 2004. Rapp. Cereca-Ifremer-Institution Adour.

Nielssen T., Prouzet P., 2008, Capture-based aquaculture of the wild European eel (Anguilla anguilla). In: Lovatelli A., Holthus P.F. (eds.). Capture-based aquaculture. Global overview. FAO Fisheries Rome, FAO, Techn. Pap. N ${ }^{\circ}$ 508, pp. 155-182.

McCleave J.D., Wippelhauser G.S., 1987, Behavioral aspects of selective tidal stream transport in juvenile American eels. Am. Fish. Soc. Symp. 1, 138-150.

Prouzet P., Lissardy M., Morandeau G., Cuende F.-X., 2001, La pêche maritime professionnelle dans l'estuaire de l'Adour en 2000 : Importance économique et caractéristiques des captures de poissons migrateurs amphihalins. Rapp. Ifremer DRV/RST/RH/2001-08.

Prouzet P. (coord.), 2002, Historique des captures de civelles, intensité actuelle de leur exploitation, variation de leur capturabilité par la pêche professionnelle maritime et indice de colonisation sur le bassin versant de l'Adour. Rapp. final, contrat EC/DG FISH (DGXIV) $\mathrm{N}^{\circ}$ 99/023. 
Prouzet P., (coord.) 2003, Etude sur la civelle (Anguilla anguilla) dans l'estuaire de l'Adour : Pêche, biologie, comportement, modélisations hydrodynamique et comportementale, estimations des flux de civelles en estuaire. Rapp. Institution Adour-Ifremer-UPPA.

Prouzet P., 2004, INDICANG: un projet pour synthétiser nos connaissances sur l'anguille et sur la qualité de ses habitats par la mise en réseau d'opérations de suivis régionaux à une échelle de dimension européenne. Chron. Eur. 54, 50-51.

Prouzet P., Bouvet J.-C., Bru N., Boussouar A., 2007, Quantification de la biomasse de civelles (Anguilla anguilla) dans l'estuaire de la Loire et estimation du taux d'exploitation saisonnier de la pêche professionnelle pour les saisons de pêche 2003 à 2005. Rapp. INDICANG, http://www.ifremer.fr/indicang/ boite-bassins-versants/pdf/rapport-saison-bv-loire.pdf

Prouzet P., Bouvet J.C., Bru N., Duquesne E., Antunes J.-C., Damasceno-Oliveira A., Boussouar A., De Casamajor M.-N., Sanchez F., Lissardy, M., 2008, Indicateurs de recrutement estuarien. In : Adam G., Feunteun E., Prouzet P. , Rigaud C. L'anguille européenne : indicateurs d'abondance et de colonisation. Coll. Savoir-faire Editions Quae, pp. 223-274.
Prouzet P., Odunlami M., Duquesne E., Boussouar A., 2009, Analysis and visualization of the glass eel behavior (Anguilla anguilla) in the Adour estuary and estimate of its upstream migration speed. Aquat. Living Resour. 22,

Rigaud C., Lafaille P., Prouzet P., Feunteun E., Diaz E., Castellano J., De Casamajor M.-N., 2008, Des compléments sur la biologie. In: Adam G., Feunteun E., Prouzet P., Rigaud C. (eds.) L'anguille européenne : indicateurs d'abondance et de colonisation. Coll. Savoir-faire éditions Quae, pp. 43-86.

Stevens Don L. Jr., Urquhart N. Scott, 2000, Response designs and support regions in sampling continuous domains. Environmetrics $11,13-41$.

Susperregui N., Boussouar A, Bru N., De Casamajor M.-N., Lissardy M., Sanchez F., Duquesne E., Prouzet P., Durozoi B., Lambert P., Paquignon G., 2007, Rapp. final Indicang : caractérisation de la pêcherie professionnelle de civelles sur l'Isle-Bassin versant Gironde-Garonne-Dordogne. http://www.ifremer.fr/indicang/ boite-bassins-versants/pdf/rapport-final-pecherie-bv-gironde. pdf 


\section{Annex}

Table A1. Nocturnal biomass estimates ( $\mathrm{kg}$ ) and exploitation rate estimates (\%), from 32 scientific surveys and corresponding environmental conditions.

\begin{tabular}{|c|c|c|c|c|c|c|c|c|c|c|c|c|}
\hline $\begin{array}{l}\text { Fishing } \\
\text { season }\end{array}$ & $\begin{array}{l}\text { Date of } \\
\text { survey }\end{array}$ & $\begin{array}{l}\hat{B}_{i}^{\text {night }} \\
(\mathrm{kg})\end{array}$ & $\begin{array}{c}\text { Reported } \\
\text { catches } \\
(\mathrm{kg})\end{array}$ & $\begin{array}{c}\hat{T}_{i} \\
(\%)\end{array}$ & TideCod & TurbCod & FlowCod & Moon & Tide coef. & Turbidity & $\begin{array}{c}\text { Temp. } \\
\left({ }^{\circ} \mathrm{C}\right)\end{array}$ & $\begin{array}{c}\text { River } \\
\text { flow } \\
\left(\mathrm{m}^{3} \mathrm{~s}^{-1}\right)\end{array}$ \\
\hline \multirow{7}{*}{ S1998-99 } & $12 / 1 / 99$ & 138 & 6.0 & 4.35 & 1 & 2 & 3 & NM & 40 & 32.18 & 6.67 & 403.5 \\
\hline & $14 / 1 / 99$ & 412 & 8.2 & 1.99 & 1 & 1 & 2 & NM & 57 & 12.67 & 6.67 & 377.8 \\
\hline & $22 / 1 / 99$ & 157 & 11.2 & 7.13 & 2 & 2 & 2 & FQ & 81 & 19.06 & 7.05 & 270.4 \\
\hline & 28/1/99 & 42 & 4.5 & 10.71 & 2 & 2 & 3 & FM & 66 & 29.84 & 8.75 & 745.9 \\
\hline & $11 / 2 / 99$ & 79 & 4.6 & 5.82 & 1 & 2 & 3 & NM & 38 & 21.08 & 7.19 & 428.8 \\
\hline & $17 / 2 / 99$ & 206 & 14.5 & 7.04 & 3 & 1 & 2 & NM & 101 & 7.44 & 6.40 & 300.5 \\
\hline & $17 / 3 / 99$ & 203 & 13.5 & 6.65 & 3 & 1 & 2 & NM & 101 & 12.67 & 12.20 & 329.5 \\
\hline \multirow{9}{*}{ S1999-00 } & $9 / 12 / 99$ & 1597 & 36.79 & 2.30 & 2 & 1 & 1 & $\mathrm{NM}$ & 78 & 3.82 & 7.38 & 142.33 \\
\hline & $22 / 12 / 99$ & 664 & 21.15 & 3.19 & 3 & 2 & 3 & FM & 100 & 28.02 & 7.33 & 440.6 \\
\hline & $5 / 1 / 00$ & 409 & 77.31 & 18.90 & 2 & 2 & 2 & NM & 71 & 17.72 & 8.26 & 288.8 \\
\hline & $7 / 1 / 00$ & 821 & 63.64 & 7.75 & 2 & 1 & 1 & NM & 78 & 12.03 & 7.76 & 234.3 \\
\hline & $8 / 1 / 00$ & 763 & 34.67 & 4.54 & 2 & 1 & 1 & NM & 79 & 10.77 & 7.82 & 220.01 \\
\hline & $9 / 1 / 00$ & 993 & 12.56 & 1.26 & 2 & 1 & 1 & NM & 78 & 9.86 & 7.86 & 206.82 \\
\hline & $12 / 1 / 00$ & 95 & 8.79 & 9.25 & 2 & 1 & 1 & FQ & 65 & 8.32 & 7.10 & 191.97 \\
\hline & $1 / 2 / 00$ & 1715 & 36.18 & 2.11 & 1 & 1 & 1 & NM & 48 & 4.15 & 7.06 & 119.27 \\
\hline & $8 / 2 / 00$ & 464 & 1.20 & 0.26 & 3 & 1 & 1 & NM & 87 & 5.28 & 9.40 & 156.8 \\
\hline \multirow{7}{*}{ S2000-01 } & $14 / 12 / 00$ & 152 & 3.2 & 2.11 & 3 & 1 & 1 & FM & 98 & 5.85 & 10.25 & 231.1 \\
\hline & $21 / 12 / 00$ & 134 & 14.7 & 10.97 & 2 & 1 & 1 & NM & 61 & 9.08 & 8.86 & 230 \\
\hline & 3/1/01 & 28 & 3.0 & 10.71 & 1 & 2 & 3 & FQ & 42 & 29.73 & 8.76 & 424.3 \\
\hline & $10 / 1 / 01$ & 659 & 11.5 & 1.75 & 3 & 2 & 3 & FM & 94 & 82.47 & 8.29 & 674.5 \\
\hline & $12 / 1 / 01$ & 81 & 18.1 & 22.35 & 3 & 2 & 3 & FM & 104 & 36.03 & 8.69 & 511.1 \\
\hline & $24 / 1 / 01$ & 218 & 64.5 & 29.59 & 2 & 2 & 3 & NM & 73 & 26.02 & 9.26 & 473.9 \\
\hline & $26 / 1 / 01$ & 132 & 45.9 & 34.77 & 2 & 2 & 3 & NM & 79 & 47.21 & 10.02 & 500.5 \\
\hline \multirow{2}{*}{ S2002-03 } & $3 / 1 / 03$ & 55 & 30.4 & 55.3 & 3 & 2 & 3 & $\mathrm{NM}$ & 88 & 83.91 & 11.30 & 784.7 \\
\hline & $22 / 1 / 03$ & 82 & 2.6 & 3.2 & 3 & 2 & 2 & LQ & 86 & 24.86 & 8.70 & 362.7 \\
\hline \multirow{2}{*}{ S2003-04 } & $26 / 11 / 03$ & 80 & 8.2 & 10.3 & 3 & 1 & 1 & NM & 102 & 7.38 & 55.80 & 178.7 \\
\hline & $21 / 1 / 04$ & 37 & 8.2 & 22.2 & 2 & 2 & 3 & $\mathrm{NM}$ & 85 & 24.45 & 24.10 & 591.9 \\
\hline \multirow{5}{*}{ S2004-05 } & $9 / 11 / 04$ & 204 & 10.3 & 5.1 & 2 & 1 & 1 & NM & 65 & 10.00 & 12.31 & 117.12 \\
\hline & $18 / 11 / 04$ & 257 & 33.8 & 13.2 & 1 & 1 & 1 & FQ & 55 & 6.00 & 8.50 & 120.59 \\
\hline & $23 / 11 / 04$ & 37 & 1.5 & 4.1 & 2 & 1 & 1 & FM & 71 & 8.00 & 9.00 & 140.5 \\
\hline & $8 / 12 / 04$ & 375 & 13.0 & 3.5 & 1 & 1 & 1 & NM & 58 & 6.00 & 8.00 & 104.5 \\
\hline & $14 / 12 / 04$ & 198 & 17.6 & 8.9 & 3 & 1 & 1 & NM & 93 & 9.00 & 9.00 & 94.55 \\
\hline
\end{tabular}


Table A2. Example of scientific data collected on January 9, 2000.

\begin{tabular}{|c|c|c|c|c|c|c|}
\hline NLT & Location & Time (h:min) & $\begin{array}{l}\text { Current speed } \\
\left(\mathrm{m} \mathrm{s}^{-1}\right)\end{array}$ & $\begin{array}{l}\text { Volume filtered } \\
\qquad\left(\mathrm{m}^{3} \mathrm{~s}^{-1}\right)\end{array}$ & $\begin{array}{l}\text { Density at } 4 \mathrm{~m} \text { depth } \\
\quad\left(\mathrm{g} 100 \mathrm{~m}^{-3}\right)\end{array}$ & $\begin{array}{l}\text { Density at the surface } \\
\left({\left.\mathrm{g} ~ 100 \mathrm{~m}^{-3}\right)}^{-3}\right.\end{array}$ \\
\hline 1 & $\mathrm{Rb}$ & $2: 45$ & 0.32 & 121.42 & 0.33 & 4.37 \\
\hline 2 & M & $2: 57$ & 0.26 & 107.39 & 3.54 & 3.98 \\
\hline 3 & $\mathrm{Lb}$ & 3:07 & 0 & 78.54 & 7.51 & 10.69 \\
\hline 4 & $\mathrm{Rb}$ & $3: 24$ & 0.31 & 121.16 & 3.74 & 9.13 \\
\hline 5 & M & $3: 37$ & 0.59 & 138.84 & 5.55 & 3.96 \\
\hline 6 & $\mathrm{Lb}$ & $3: 53$ & 0.25 & 117.27 & 2.3 & 8.46 \\
\hline 7 & $\mathrm{Rb}$ & $4: 01$ & 0.39 & 136.32 & 3.45 & 2.93 \\
\hline 8 & M & $4: 27$ & 0.78 & 133.90 & 7.32 & 11.43 \\
\hline 9 & $\mathrm{Lb}$ & $4: 36$ & 0.57 & 115.79 & 4.92 & 6.26 \\
\hline 10 & $\mathrm{Rb}$ & $4: 47$ & 0.48 & 125.15 & 4.71 & 6.07 \\
\hline 11 & M & $4: 57$ & 0.89 & 132.60 & 9.5 & 13.05 \\
\hline 12 & $\mathrm{Lb}$ & 5:07 & 0.76 & 137.19 & 4.37 & 5.83 \\
\hline 13 & $\mathrm{Rb}$ & $5: 17$ & 0.49 & 126.97 & 2.05 & 3.39 \\
\hline 14 & M & $5: 28$ & 0.86 & 142.99 & 7.62 & 6.29 \\
\hline 15 & $\mathrm{Lb}$ & $5: 47$ & 0.25 & 133.03 & 3.23 & 4.74 \\
\hline 16 & $\mathrm{Rb}$ & $5: 58$ & 0.50 & 147.15 & 3.47 & 7.00 \\
\hline 17 & M & $6: 08$ & 0.44 & 145.51 & 7.49 & 11.00 \\
\hline 18 & $\mathrm{Lb}$ & $6: 20$ & 0.35 & 151.05 & 4.04 & 3.11 \\
\hline 19 & $\mathrm{Rb}$ & $6: 31$ & 0.28 & 141.43 & 2.26 & 4.95 \\
\hline 20 & M & $6: 41$ & 0.29 & 133.03 & 4.13 & 11.28 \\
\hline 21 & $\mathrm{Lb}$ & $6: 51$ & 0.01 & 113.54 & 3.58 & 2.99 \\
\hline
\end{tabular}

NLT: rank of the longitudinal transect, Rb: right bank, M: middle of the river, Lb: left bank. 